\title{
Performances of Direct Alcohol Fuel Cells using Mordenite Composite Membranes
}

\author{
R. Gokulakrishnan ${ }^{1 *}$, A. S. Perumal' and N. Manoharan ${ }^{2}$ \\ 'Department of Naval Architecture \& Offshore Engineering, AMET University, INDIA; \\ krishfred@gmail.com, Perumal.as@ametuniv.ac.in \\ 2Directorresearch, AMET University, India; Directorresearch@ametuniv.ac.in
}

\section{Introduction}

Polymer Electrolyte Membrane Fuel Cells (PEMFC) are clean and efficient energy conversion devices that are promising alternative power sources for portable, transportation, and stationary applications. Direct Methanol Fuel Cells (DMFC) and Direct Ethanol Fuel Cells (DEFC), a subclass of Polymer Electrolyte Membranes Fuel Cells (PEMFC) are currently considered as promising candidates for effective power sources. The use of hydrogen as a fuel offers disadvantages over the use of methanol such as costly, difficult transportation and safety. Methanol also has high mass energy density (about $21.2 \mathrm{MJ} \cdot \mathrm{kg}-1)^{1}$.

In addition, the use of ethanol as a fuel also offers several advantages such as high energy density (about 26.8 MJ.kg-1) $)^{1}$, non-toxic, renewable and can be easily produced in great quantity by the fermentation of sugarcontaining raw materials ${ }^{2}$. In addition, ethanol can be submitted over a full cycle with zero green house contribution to the atmosphere. DuPont Nafion ${ }^{\circ}$ is the most widely used as Proton Exchange Membrane because of its physical properties are suitable for the application of chemical resistance and withstand temperatures up to $80-100^{\circ} \mathrm{C}^{3-12}$. However, some challenges such as the presence of ethanol in the cathode, due to the crossover through the Nafion ${ }^{\circ}$ membrane ${ }^{13}$, should be taken into consideration because of reduction in the open circuit voltage ${ }^{2,13}$. At the same time, the permeated ethanol and its oxidation of the intermediate products could poison the cathode catalyst ${ }^{2}$. The research has studied and improved by the addition of zeolite into the polymer membrane $e^{3,10,14}$. The inorganic substances, which are crystalline, are resistant to heat and have the ability to absorb water. Mordenite was used as an additive because of its ability to absorb water better than alcohol and behaves like a ethanol blocking material into the water channels of Nafion ${ }^{3}$. Normally, proton conduction through a Nafion membrane occurs mainly through water channels within the matrix ${ }^{12,15}$. By incorporating a mordenite, composite membrane is improved because of travelling of ethanol through a tortuous pathway to reach the cathode whilst a pathway for protons is available ${ }^{3}$. However, incorporating zeolite into the Nafion membrane is also have a problem of the incompatibility of the inorganic zeolite crystals and polymer matrix, then nanometre-scale pinholes can form at the interface between them ${ }^{3}$, facilitating ethanol transport. In order to overcome this problem, the research has grouped zeolites with silane-coupling agents ${ }^{3,5,11,14}$ prior to incorporate in Nafion membrane. The research has reported zeolite can be functionalized with silane coupling agents, such as (3- mercaptopropyl)trimethoxysilane (MPTS) ${ }^{5}$ and gamma-glycidoxypropyltrimethoxysilane (GMPTS $)^{16}$. The aim of functionalizing mordenite with silane coupling agent is in order to eradicate the formation of pinhole within the composite membrane.

\section{Experimental}

\subsection{Preparation of Zeolite}

Mordenite- $\mathrm{H}$ was added into polymer membrane following this procedure. First step, purchased mordenite (Zeolyst) was wet ground in a ball mill into submicron scale. Then, it was ion-exchanged in $1 \mathrm{M}^{\text {of }} \mathrm{H}_{2} \mathrm{SO}_{4}$ solution to change mordenite-Na to mordenite- $\mathrm{H}$. Then, mordenite- $\mathrm{H}$ was functionalized with silane coupling agent by taking $4 \mathrm{~g}$ of mordenite- $\mathrm{H}$ in a mixture of $4 \mathrm{ml}$ GMPTS 
and $120 \mathrm{ml}$ dichloromethane and mixed by magnetic stirrer for $24 \mathrm{~h}$ under the room temperature. With MPTS, $4 \mathrm{~g}$ of mordenite- $\mathrm{H}$ was refluxed at $110^{\circ} \mathrm{C}$ in a mixture of $80 \mathrm{ml}$ toluene and $8 \mathrm{ml}$ MPTS for $24 \mathrm{~h}$. The mixture then was centrifuged at $6000 \mathrm{rpm}$, decanted and re-dispersed in ethanol in an ultrasonic bath to remove any unreacted silane. Finally, functionalized mordenite was dried at $100^{\circ} \mathrm{C}$ for $24 \mathrm{~h}$.

\subsection{Preparation of Composite Membranes}

The designated thickness of composite membrane was $\mathrm{m}$. The solution of $20 \mathrm{wt} \%$ Nafion solution (Ion Power, Inc), was mixed with the mixture of methanol, ethanol and $\mathrm{N}, \mathrm{N}$-dimethylformamide (DMF). Then, functionalized mordenite was added to the mixture. The suspension was dispersed using ultra-sonication and magnetic stirrer for 15 minute intervals for $2 \mathrm{~h}$. Then, the solution was poured in petri dish and was recast in vacuum oven under the temperature of $80^{\circ} \mathrm{C}$ for $20 \mathrm{~h}$ and afterwards under $160^{\circ} \mathrm{C}$ for $4 \mathrm{~h}$ to ensure the removal of all volatile compounds. Finally, take the dried membrane was from petri dish, wash and boiled in deionized water and $1 \mathrm{M}$ sulfuric acid respective.

\subsection{Single Cell Performance Testing}

This test was carried out in a single cell of a DAFC in order to determine the fuel cell employing composite membrane. The feed was $1 \mathrm{M}$ of ethanol and $1 \mathrm{M}$ of methanol. The MEA comprised of electrode with $1 \mathrm{mg} \cdot \mathrm{cm}^{-2}$ of $\mathrm{Pt}-\mathrm{Ru} / \mathrm{C}$ (40:60) and $1 \mathrm{mg} \cdot \mathrm{cm}^{-2}$ of $\mathrm{Pt} / \mathrm{C} \mathrm{(40:60)}$ at anode and cathode respectively. Both electrodes were assembled with composite membrane. Reaction area of electrode was $4.5 \square 4.5 \mathrm{~cm} 2$. In operation, $1 \mathrm{M}$ of ethanol and methanol solution was fed at $5 \mathrm{ml} \cdot \mathrm{min}^{-1}$ at anode side and air with the flow rate of $1000 \mathrm{ml} \cdot \mathrm{min}^{-1}$ at cathode side. The tests were carried out at $40^{\circ} \mathrm{C}$ and $80^{\circ} \mathrm{C}$.

\subsection{Single Cell Performance Testing}

The process flow diagram of the experimental system of DAFC test station is schematically presented in Figure 1. On the anode side, fuel is stored in a storage tank and was delivered to the anode side of the fuel cell by a peristaltic pump. The solution flows into the cell at the lower inlet and excess alcohol, water and $\mathrm{CO}_{2}$ gas produced leave the cell at the upper outlet. The flow rate of the solution is regulated by calibrating the pump speed. On the cathode

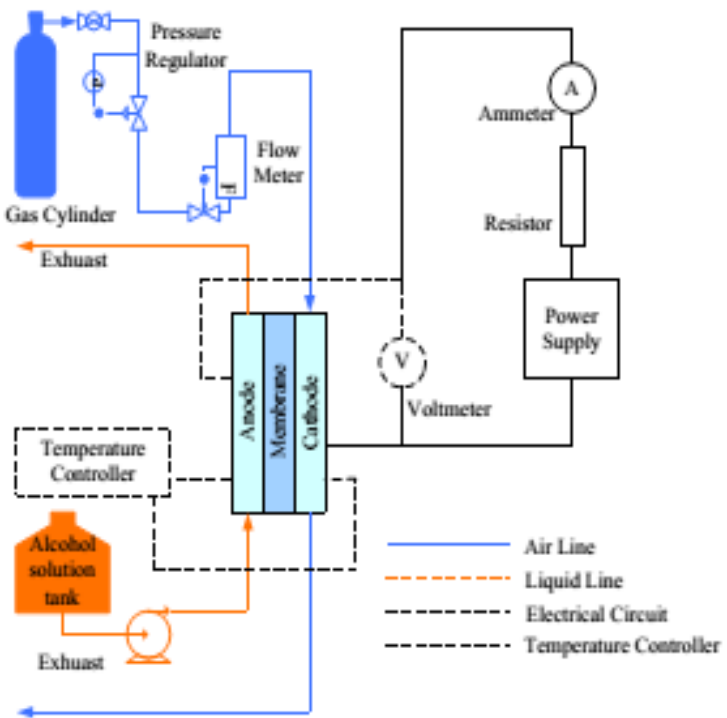

Figure 1. Process flow diagram of the experimental system $^{3}$

side, gas was supplied from a gas cylinder through the main valve. The flow rate of the gas was controlled and monitored by an air flow meter. Gas was fed into the upper inlet of the cell and excess gas and water produced were released into the atmosphere. At the fuel cell testing unit, cell potential and current were monitored by an ammeter and a voltmeter respectively. An external power supply (TTi EX1810R) was used for controlling current flowing through the cell. Cell temperature was controlled by a temperature controller together with a thermocouple and electric heaters.

\section{Results and Discussion}

\subsection{Performance of Composite Membrane in DEFC}

For the DMFC test with $1 \mathrm{M}$ methanol solution, the results are shown in Figure 1. It can be seen that at $40^{\circ} \mathrm{C}$, in (a), MPTS-MOR, Unfunctionalzed mordenite (MOR-H), GMPTS-MOR and recast membrane gave the maximum power density of $8.67,8.53,6.27$ and $5.95 \mathrm{~mW} \cdot \mathrm{cm}^{-2}$ respectively. The results were $38.27 \%, 36.04 \%$ higher than that of standard Nafion, while GMPTS-MOR membrane was $5.10 \%$ lower. At $80^{\circ} \mathrm{C}$, in (b), MPTS-MOR, GMPTSMOR, Recast and MOR-H membrane gave maximum power density of $22.71,20.45,15.21$ and $13.52 \mathrm{~mW} \cdot \mathrm{cm}^{-2}$, respectively. It was $49.30 \%$ and $34.45 \%$ from MPTS and 
GMPTS higher than that of standard Nafion, whereas MOR-H gave $11.11 \%$ lower.

It can be seen that membrane with mordenite modified by coupling agent shows higher direct methanol fuel cell performance.

\subsection{Performance of Composite Membrane in DMFC}

In DEFC test with $1 \mathrm{M}$ ethanol solution, the results were shown in Figure 2. At $40^{\circ} \mathrm{C}$, (a), MPTS-MOR, MOR-H, Recast and GMPTS membrane gave maximum power density of $2.32,2.09,1.93$ and $1.78 \mathrm{~W} \cdot \mathrm{cm}^{-2}$, respectively, which were $20.20 \%$ and $8.29 \%$ higher than standard Nafion, while GMPTS membrane gave $7.77 \%$ lower. At $80^{\circ} \mathrm{C}$, (b), GMPTS, MPTS, Recast and MOR-H membranes gave maximum power density of $4.21,4.10$, 4.05 and $3.04 \mathrm{~mW} \cdot \mathrm{cm}^{-2}$. When the results were compared with standard Nafion, GMPTS and MPTS gave power density $3.90 \%$ and $1.23 \%$ higher, while MOR-H was $24.93 \%$ lower.

\section{Conclusion}

Nafion/mordenite-GMPTS and Nafion/mordenite-MPTS composite and Nafion/MOR-H membrane were synthesized using solution recasting technique and tested in a

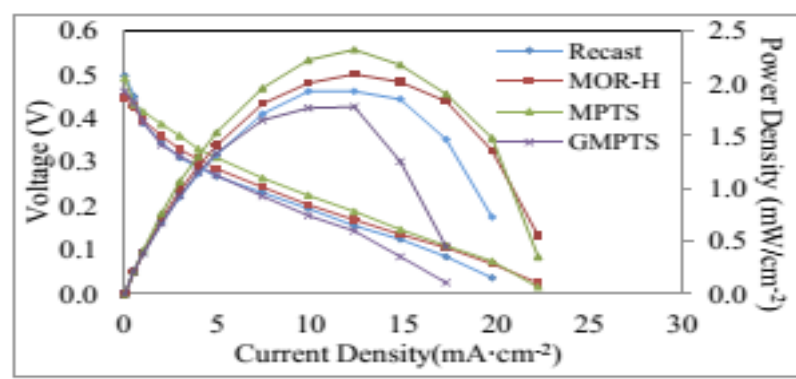

(a)

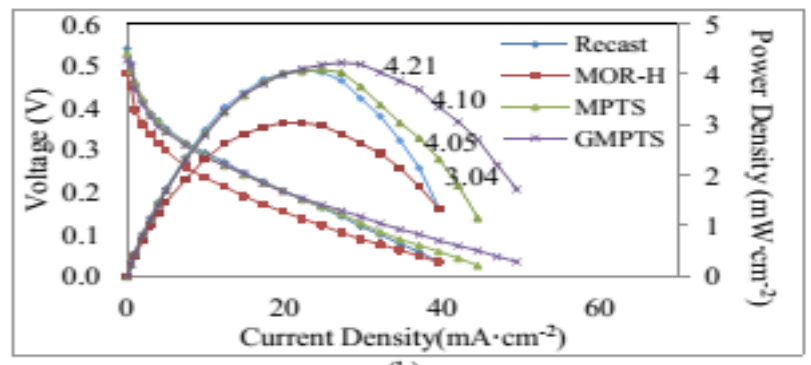

(b)

Figure 2. Polarization curve of DMFC with methanol (a) $40^{\circ} \mathrm{C}$ and (b) $80^{\circ} \mathrm{C}$ single cell of DMFC and DEFC. The results were compared to that of standard Nafion membrane. The composite membranes and with functionalized mordenite could be used in DAFC applications. The functionalization with membrane coupling agents could improve the performance of the membrane in fuel test in both DMFC and DEFC as the results from MPTS and GMPTS gave higher performance than unfuntionalized MOR-H membrane.

\section{References}

1. Mann J, Daubin MS, Bocarsly AB. Catalysts for direct ethanol fuel cells. 2004; Chemistry Department, Princeton University; Princeton, NJ: 08544.

2. Andreadis G, Tsiakaras P. Ethanol crossover and direct ethanol PEM fuel cell performance modelling and experimental validation. Chem Eng Sci. 2006; 61:7497-508

3. Yoonoo C, Dawson CP, Robert EPL, Holmes SM. Nafionmordenite composite membranes for improved methanol fuel cell performance. J Membr Sci. 2010; 369: 367-74

4. Haubold H, Vad Th, Jungbluth H, Hiller P. Nano structure of NAFION: a SAXS study. Electrochim Acta. 2001; 46: 1559-63

5. Yen C, Lee C, Lin Y, Lin H, Hsiao Y, Liao S, Chuang C, Ma CM. Sol-gel derived sulfonated-silica/Nafjion composite membrane for direct methanol fuel cell. J Power Sourc. 2007; 173:36-44

6. Alzate V, Fatih K, Wang H. Effect of operating parameters and anode diffusion layer on the direct ethanol fuel cell performance. J Power Sourc. 2011; 196: 10625-31

7. Mukoma P, Jooste BR Vosloo HCM. A comparison of methanol permeability in Chitosan and Nafion 117 membranes at high to medium methanol concentrations. J Membr Sci. 2004; 243:293-9

8. Ramya K, Dhathathreyan KS. Direct methanol fuel cells: determination of fuel crossover in a polymer electrolyte membrane. J Electroanal Chem. 2003; 542: 109-15

9. Ge J, Liu H. Experimental studies of a direct methanol fuel cell. J Power Sourc. 2005; 142: 56-69

10. Kongkachuichay P, Pimprom S. Nafion/Analcime and Nafion/Faujasite composite membranes for polymerelectrolyte membrane fuel cells. Chem Eng Res Des. 2010; 88: 496-500

11. Li C, Sun G, Ren S, Liu J, Wang Q, Wu Z, Sun H. and Jin W.; Casting Nafion-sulfonated organosilica nano-composite membranes used in direct methanol fuel cells, J Membr Sci. 2006; $272:$ 50-7

12. Liyanage AD, Ferraris JP, Musselman IH, Yang, Andersson TE, Son DY et al. Nafion- sulfonated dendrimer composite membranes for fuel cell applications. J Membr Sci. 2012; 392-393:175-80 
13. Yoonoo C. Development of Nafion-mordernite composite membranes for direct methanol fuel cell application $[\mathrm{PhD}$ Thesis]. The University of Manchester; 2010.

14. Intaraprasit N, Kongkachuichay $\mathrm{P}$. Preparation and properties of sulfonated poly(ether ether ketone)/Analcime composite membrane for a proton exchange membrane fuel cell (PEMFC). J Taiwan Instit of Chem Engin. 2011; 42:190-5
15. Peighambardoust SJ, Rowshanzamir S, Amjadi M. Review of proton exchange membranes for fuel applications. Int J Hydrogen Energ.2010; 35:9349-84

16. Wang Y, Jiang Z, Li H, Yang D. Chitosan membranes filled by GPTMS-modified zeolite beta particles with low methanol permeability for DMFC. Chem Eng Process. 2010; 49:278-85 